\title{
Doctoral Research Supervision-Team Approach and Perspective of Socratic Method at the University of Rwanda (UR): Opportunity for Innovation
}

\author{
Father Dr. Lucien Hakizimana* \\ University of Technology and Arts of Byumba (UTAB), Rwanda \\ *Corresponding Author: Father Dr. Lucien Hakizimana, University of Technology and Arts of Byumba \\ (UTAB), Rwanda
}

\begin{abstract}
This study investigated how the "Doctoral research supervision-team approach and perspective of Socratic Method can improve innovation at the University of Rwanda (UR). It has been proved that most of doctoral candidates are stuck along their research and then they have difficulties to have enough findings. Doctoral research supervision-team approach (2 or 3 supervisors per 1 doctoral candidate) has been adopted by UR as a way of mitigation. Eighty-seven per cent (87\%) of our respondents attested that this approach helps doctoral candidates to work together with their supervisors and hence there is a possibility of innovation. With research supervision-team, one hundred per cent (100\%) of doctoral candidates confirmed that they may have a wide range of knowledge, abilities and confidence, but all (supervisors and supervisee) should work toward the same goal.
\end{abstract}

This research was guided by the following objectives: the main objective was to prove how doctoral research supervision-team approach embedded with Socratic Method can improve doctoral candidates' innovation. Specific objective was to discover how Socratic Method reduces candidates' lack of confidence in their doctoral research.

The methods used were quantitative and qualitative. Findings of this study showed that there is a quality improvement in doctoral research when supervisors are working in team what enhances innovation at UR.

Keywords: Doctoral Research, Supervision-Team, Research, Supervision, candidates, Innovation, Supervisor, University of Rwanda (UR), Socratic Method

\section{INTRODUCTION}

We undertook this research after discussing with some $\mathrm{PhD}$ graduates who related that they have been discouraged and stressed by the lack of enough findings along their research's journey. After our discussion I wanted to analyze the research supervision in colleges of the University of Rwanda (UR) and their way of mitigation with the purpose of targeting how to maximize the possibility of innovation. Research-supervision at UR colleges is composed of two or three supervisors for one doctoral candidate who meet to discuss on the research or interact online.

In traditional research supervision methodologies, one supervisor leads the research process and a doctoral candidate works individually on research and sometimes "relationships with the supervisor can be difficult and personally devastating""

The traditional process of the research supervision presents many challenges to both the supervisor and the supervisee. Although a traditional supervision may be effective for efficiently guiding the supervisee in one way, this promotes superficial findings and discouragement, lack of confidence and enthusiasm on the other way ${ }^{2}$.

Our respondents acknowledged that the purpose of research supervision-team approach is to promote better communication as well as to foster an increase in a variety of thinking strategies among

\footnotetext{
${ }^{1}$ OSSREA, (2013): PhD Training in Eastern and Southern Africa: The experience of OSSREA, Tekeste Negash and Abiye daniel, Addis Abeba: 183.

${ }^{2}$ Weimer,2002.
} 
supervisors and supervisee. However, the results of our findings showed that a kind of scientific dialogue which we qualified as Socratic Method embedded in research supervision-team approach should be improved in order to increase the productivity. Let's clarify the idea of our respondents through this quotation: "Socrates was aware, that each individual must seek the grounds of his own conviction that truth is not something given from out, but must be found by the exercise of a man's own thought" " Through their discussions, the Socratic Method is a good way to dig and find out the truth and innovation.

At UR, as it has been confirmed by interviewed supervisors, several research process styles are encouraged in supervision-team approach to provide to doctoral candidate with varied tools and research methodologies, creating a better environment for candidate to research and innovation. With the use of valuable research skills, candidates are capable of achieving lifelong research goals, which can enhance candidate's capability of innovation.

In this framework, at the end of this study, following the views of our respondents, we observed that the methods of supervising at UR should be improved with Socratic Method to increase more the quality and innovation.

A good collaboration within research supervisors and a doctoral candidate helps the later feel confident in his/her journey of research and then he/she can innovate. It is very helpful in innovation when the same concept or the same reality is understood in different ways and then produces improved results.

\section{Methodology}

UR has a total number of 7 colleges which have PhD program by research. Here, the simple random sample was used to candidates for interview and responding to our questionnaire. Second, the purposive sample was used and the total number of our respondents is 8 supervisors and 22 candidates.

To get quantitative data, the questionnaire has been distributed to our respondents with objective to obtain data with regard to our investigation. In fact, basing on the size of the sample, a set of open ended and close questions have been prepared for this research. The questionnaire was also used because it would satisfy the assumptions on which it was based ${ }^{4}$.

On the other hand, the technique of interview required to ask questions to some supervisors and supervisees in order to get qualitative data. Sometimes respondents also asked questions and the interviewer responded to them, but usually the interviewer initiated the interview and collected the information. Regarding formal interviews, respondents were asked similar questions but they were allowed to express their opinions and this gave more information regarding the study.

\section{RESUltS}

\subsection{The Role of Supervision-Team Approach in Research Process}

The research supervision-team approach engages a doctoral candidate as well as supervisors in the hard work of researching. This is important because doctoral candidates cannot develop sophisticated research skills without the guide of supervisors.

Most of such research activities involve problem-solving and investigational work, and involve collaboration with supervisors. So the research supervision-team allows doctoral candidates to be more active and take responsibilities in the research process. With this, they are also independent and able to apply the acquired skills.

In this way, the supervision-team plays a role of a facilitator by giving instructions, providing guidance, monitoring candidates' research as well as inviting them to go deep in their innovation. Our

\footnotetext{
${ }^{3}$ L. Frick, R. Albertyn, R. Rutgers, (2010): The Socratic Method: Adult Education Theories, Stellenbosch University: 76.

${ }^{4}$ Leedy\&Ormrod, (2002): Practical Research: Planning and Design, 10th Edition. Paul D. Leedy, Late of The American University: 202.
} 
respondents confirmed that supervision-team's role is to make sure that the research is being a worthy and gives clear way of innovation ${ }^{5}$.

This approach encourages supervisors and supervisee to reflect on what they are searching and how they are searching it ${ }^{6}$. Even in casual conversations, they talk about what they are searching, they challenge some assumptions and encourage themselves to accept responsibility for decisions they make about research ${ }^{7}$. Research supervision-team approach includes assignment components in which supervisors and supervisee reflect, analyze and criticize what they are discovering and how they are discovering it. The goal is to make a doctoral candidate aware of him/her self as researcher and to make research skills something he/she wants to develop. In this sense, embedded with Socratic Method, what a doctoral candidate already knows largely determines what the new information he attends to, how he/she organizes and represents new information, and how he filters new experiences, and even what he/she determines to be important or relevant ${ }^{8}$.

Our respondents confirmed that a scientific discussion guided by a kind of Socratic Method enhances strategic processing and executive control. The ability to reflect on and regulate one's thoughts is an essential aspect to reach innovation. Through Socratic Method, a doctoral candidate is involved in his/her own research, monitors his/her thinking, and assumes responsibility for his/her own research ${ }^{9}$. The benefits include increased motivation for research and greater satisfaction; both of these outcomes lead to greater achievement ${ }^{10}$. Research shows that personal involvement, intrinsic motivation, personal commitment, confidence in one's abilities to succeed, and a perception of control over discovering lead to more discovering and higher achievement ${ }^{11}$.

Seventy-five per cent $(75 \%)$ of our respondents acknowledged the possibility of individual progress which can be influenced by both inherited and environmental factors when the research is conducted with Socratic Method. Depending on the context or task, changes in how people think and believe, or depending on a combination of one's inherited abilities, stages of development, individual differences, capabilities, experiences, and environmental conditions. ${ }^{12}$ If Socratic Method is exploited, our respondents attested that innovation can be achieved. The role of supervisors remains to ensure that a doctoral candidate constructs his/her own knowledge through his/her constant progress reports.

\subsection{Meeting and Responsibilities in Doctoral Research}

Having 2 or 3 supervisors, doctoral candidates are requested to work more because every supervisor brings his input on the research. A doctoral candidate uses many different techniques to reach objectives predicted by each supervisor in research process ${ }^{13}$. His/her commitments cannot be successful if the dialogue under the form of Socratic Method is not involved.

Discussing with UR supervisors, it came out that Socratic Method is efficient because doctoral candidate becomes engaged and challenged in thinking using real life and imaginary situations. In fact, "in the classical Socratic dialogues, Socrates takes on the role of the critical friend, questioning his students to enable them to arrive at an understanding of their reasoning and argument" ${ }^{\prime 14}$. If they

\footnotetext{
5 "Socrates was aware, that each individual must seek the grounds of his own conviction, that truth is not something given from out, but must be found by the exercise of a man's own thought. He required all assumptions to be examined anew, no matter how old or how current they were, and that dependence should only be placed on proof and not on authority (Zeller \& Reichel 1868: 95)" L. Frick, R. Albertyn, R. Rutgers, (2010): 76.

${ }^{6}$ Weimer (2012): 213.

7 Thomas J. Sergiovanni; Robert J.Starratt; Vingent Cho, (2014): Supervision: A redefinition, $9^{\text {th }}$ Edition, McGraw-Hill, New York: 87.

${ }^{8}$ Murphy \&Alexander, (2000): 25.

${ }^{9}$ N. Lambert, \& B. McCombs (Eds.), (2000): How students learn, Washington, D.C.: American Psychological Association: 15

${ }^{10}$ Roger T. and David W. Johnson, (1991) An Overview Of Cooperative Learning: 27.

${ }^{11}$ Murphy \&Alexander, (2000): 48

${ }^{12}$ Murphy \&Alexander, (2000):73

${ }^{13}$ Bonwell, C. C., \& Eison, J. A. (1991). Active Learning: Creating Excitement in the Classroom. ASHE-ERIC Higher Education Report, Washington DC: School of Education and Human Development, George Washington University: 23.

${ }^{14}$ L. Frick, R. Albertyn, R. Rutgers, (2010): 76.
} 
apply this Method, UR supervisors admitted that a doctoral candidate becomes engaged in deeper thinking about research outlines and its content, he/she brings additional knowledge to the science, and group discussion between supervisors and the candidate brings up ideas, solve problems or comments. This group discussion is also a place where a candidate expresses his/her thoughts on his/her discoveries. On the side of supervisors, by Socratic Method it is a valuable place to check and see if a doctoral candidate understands the method which is guiding him/her to the objectives and good results. "The Socratic method is a beneficial way of helping students during the course of their research process. It can be used at various stages when a student feels stuck and can contribute towards the student's research identity" ${ }^{\prime 15}$.

The reason why the Socratic Method is suitable for research supervision-team is that it removes fear and embarrassment from doctoral candidate in group discussion. In most cases at UR when supervisors and a supervisee are discussing, it helps the supervisors to supervise the doctoral candidate's atmosphere so that the student is free to active research with expressing his/her views. This favors a student to review his/her work enhancing knowledge and looking for its assumptions. The doctoral candidate becomes co-creator of knowledge ${ }^{16}$.

Conducting this research, supervisors of UR confirmed that there are several pedagogical and ideological reasons why UR uses supervision-team approach. Leathwood (2001) stated that the reasons for group work rely on interdependence and this one fosters a value of research effort ${ }^{17}$. That is to say that research supervision-team approach as interactive searching facilitates the development of interpersonal skills and then can generate innovation.

Basing on the idea of Mc Kinney, Kathleen (2010) this interaction is an active way to search because each researcher takes a position and gather information to support his/her view and explains it to others ${ }^{18}$. These interactions between supervisors and supervisee not only give the candidate a chance to participate in a scientific discussion but it also lets him/her gain some experience and be confident when he/she is discovering ${ }^{19}$.

However, during our research, it has been raised the fact that sometimes supervisors miss to meet appointments given to supervisee due to multiple factors. Some respondents said that a supervisor's reluctance is due to misunderstanding with other supervisors about certain cases of research but UR is seeing how to handle such situations. This misunderstanding is based also on cultural identity as supervisors come from different cultures.

Other respondents revealed that to participate in group discussion for some supervisors is a big problem. They revealed that some doctoral candidates complain about passive supervisors while others are active in group discussions. More often low participation is caused by the fact that supervisors are overwhelmed by other academic activities.

In general, respondents highlighted that supervisors may not be the only expert during research processes, but they can still play key role in offering support in literacy skills, help a doctoral candidate navigate the breadth of content and apply methods and techniques properly.

\subsection{Research Supervision-Team Approach towards Innovation}

At UR, research supervision-team approach is conceived for conveying a variety of new information and materials to doctoral candidate. Supervisors ( 2 or 3 people at UR) can share information among them or among them and doctoral candidate. The supervision is often designed to address the gap between the current knowledge and what supervisors think they ought to discover with doctoral candidate. Supervisors help select the material best suitable to meet the scientific needs in the domain of knowledge and provide instruction, online or in meeting, that can switch on innovation. Supervisors take into consideration three specific methods to be mixed for the purpose of innovation.

\footnotetext{
${ }^{15}$ L. Frick, R. Albertyn, R. Rutgers, (2010): 94.

${ }^{16}$ McKinney, Kathleen and Chick, Nancy L. (2010) "SoTL as Women's Work: What Do Existing Data Tell Us?," International Journal for the Scholarship of Teaching and Learning: Vol. 4: No. 2: 16.

Leathwood, C. (2001): The road to independence? Policy, pedagogy and "the independent learner" in higher education, University of East London: 17.

${ }_{18}^{18}$ McKinney, Kathleen and Chick, Nancy L. (2010) : 16.

19 Commins, (1983) Mapping Reality: An Evolutionary Realist Methodology for the Natural and Soscial Sciences.
} 


\subsubsection{Direct Supervision}

Remaining in the line of research supervision-team approach, at UR, direct supervision is an approach which is being used to provide instruction to a doctoral candidate. However, when the same instructions are being provided to the candidate, they are being shared between supervisors in order to have the same way in supervision. Direct supervision requires that supervisors clearly understand the overall content, as well as the appropriate order of knowledge ${ }^{20}$. A thorough understanding of the subject supports both the research's objectives and the researcher's order of presentation. It allows also supervisors to evaluate the results for a doctoral candidate more closely so that together they can address further research needs.

In direct supervision, UR supervisors attested that they maintain a large amount of control over both the information being searched and the method of researching. Converging with Thomas J. et al., (2014), UR supervisors direct and channel the flow of information and material so that a doctoral candidate can seek the knowledge at an optimal rate ${ }^{21}$. As a result, direct supervision is considered to be one of the most efficient methods, allowing a doctoral candidate to make progress at a steady pace $^{22}$.

\subsubsection{Indirect Supervision and Socratic Method Embeddedness}

Our respondents highlighted the necessity of a fruitful dialogue between UR supervisors and UR doctoral candidates as perspective to be adopted. This perspective has been understood as a Socratic method. The idea of L. Frick et al. helps us clarify it:

"Supervisors often encounter postgraduate students who struggle to formulate their ideas coherently, take ownership of their own research projects, become independent and/or find their scholarly voices. Supervisors started to experiment with the Socratic method as an approach to facilitate students' becoming, and achieved varying degrees of success. Supervisors were urged to delve more deeply into the theories that underscored their questioning practices" 23 .

Indirect supervision is based on the fact that doctoral candidates should be guided by supervisors toward attaining new knowledge in a subject on their own ${ }^{24}$.

Applying indirect supervision, UR supervisors said that initially they give a candidate strategies that enable him/her to identify issues or problems. Using Socratic approach, the doctoral candidate is assisted to break down the issues into smaller units, and problem solving is focused on each of the smaller units rather than the main issue. This process continues until a big number of the smaller units have been overturned to resolve the larger issue. In this way, Socratic Method helps in the research journey towards innovation. UR supervisors are supposed to continue to give prompts and encouragement to aid the candidate's progress until the candidates master how to solve the problems in generalized situations. As the candidate begins to get suitable information and applies it successfully, he/she gradually takes on more responsibility, ultimately becoming more independent by requiring less assistance. In indirect supervision, candidate receives supervisors' assistance in helping him/her master skills and attain knowledge quickly and efficiently ${ }^{25}$.

\subsubsection{Socratic Method}

All our respondents recognized the relevance of a good scientific dialogue between supervisors and supervisee, what in our research we called Socratic Method. In this framework, research supervisionteam approach fosters a reciprocal interaction. They said that this dialogue should happen mainly in

\footnotetext{
${ }^{20}$ OSSREA, (2013): PhD Training in Eastern and Southern Africa: The experience of OSSREA, Tekeste Negash and Abiye daniel, Addis Abeba: 183

${ }^{21}$ Thomas J. Sergiovanni; Robert J.Starratt; Vingent Cho, (2014): Supervision: A redefinition, $9^{\text {th }}$ Edition, McGraw-Hill, New York: 31.

${ }^{22}$ OSSREA, (2013): 183.

${ }^{23}$ L. Frick, R. Albertyn, R. Rutgers, (2010): 77.

${ }^{24}$ OSSREA, (2013): 184.

${ }^{25}$ Johnsen, Scott, "Improving Achievement and Attitude Through Cooperative Learning in Math Class" (2009): Action Research Projects: 64. https://digitalcommons.unl.edu/cgi/viewcontent.cgi?article=1029\&context=mat hmidactionresearch (Retrieved on $4^{\text {th }}$ Jam7nuary 2019).
} 
meeting and sometimes online. It is a kind of debate between supervisors and supervisee discussing points of clarification ${ }^{26}$.

We qualified what has been suggested by our respondents as Socratic Method where by doctoral candidates need an improvement because some supervisors interact with them only with a kind of direct supervising (supervision approach seen above on 3.1.). Long the supervision, doctoral candidates suggest that their supervisors should develop techniques of dialogues: questioning, asking to clarify, and to predict. If we refer to L. Frick et al., in such dialogues, Socrates continuously posed questions, but did not provide answers, advice or solutions to his students' ponderings. He didn't openly disagree with any argument put forth by his students, but rather continued to question in order students arrive at their own answers ${ }^{27}$.

In their interactions with supervisors, through Socratic Method, doctoral candidates should be questioned about key issues in the material, clarify difficult sections of content, and predict the outcome. In this perspective, Maxwell, W. acknowledges the power dynamic inherent in the supervisory relationship which enhances students' ownership and control of their postgraduate research process. ${ }^{28}$

As supervisors present the material, they gradually shift the responsibility to the doctoral candidate, enabling him/her to think critically about what he/she is doing. In this way, Socratic Method is considered to be one of the most effective supervision methods as it enhances candidate's critical thinking in research ${ }^{29}$.

\section{CONCLUSION}

The data of this research have been collected from 8 UR supervisors and 22 UR doctoral candidates. After our discussion on doctoral research supervision-team approach and perspective of Socratic Method the results showed that our respondents are recognizing the possibility of increase in confidence in research process if this kind of supervision is embedded with Socratic Method. About the question regarding the confidence in this kind of supervision, $100 \%$ of respondents agreed with the statement.

Regarding the question concerning innovation, eighty seven (87\%) confirmed that working in group helps a doctoral candidate understand concepts better what should be the basic for innovation. These results showed us that some students like to be supervised by a team of supervisors and only $13 \%$ were neutral because they are starting $\mathrm{PhD}$ and don't have enough information.

\section{REFERENCES}

[1] Bernero, J. (2000): Motivating student in math using cooperative learning.( ERIC Document Reproduction service $\mathrm{N}^{\mathrm{o}}$ ED446999).Bonwell, C. C., \& Eison, J. A. (1991): Active Learning: Creating Excitement in the Classroom. ASHE-ERIC Higher Education Report, Washington DC: School of Education and Human Development, George Washington University.

[2] Commins, (1983): Mapping Reality: An Evolutionary Realist Methodology for the Natural and Soscial Sciences.

[3] Dewey J (1933): How do we think. Boydston (ed) 1933: 177-356.

[4] Egan, Hyde and Ruth, Litz (2003): The Effects and Importance of Classroom Participation.

[5] Frick L., Albertyn R., Rutgers R., (2010): The Socratic Method: Adult Education Theories, Stellenbosch University.

[6] Johnsen, Scott, "Improving Achievement and Attitude Through Cooperative Learning in Math Class" (2009): Action Research Projects. 64. https://digitalcommons.unl.edu/cgi/viewcontent.cgi?article=1029\& context=mathmidactionresearch (Retrieved on $4^{\text {th }}$ Jam7nuary 2019).

[7] Johnson, D., Johnson, R. (1975): Learning together and alone, cooperation, competition, and individualization. Englewood Cliffs, NJ: Prentice-Hall.

[8] Kumar, M. (2006):“Constructivists epistemology in action”. Journal of Educational Thought, Vol.40, No. 3, pp. 246-262. ISSN: 2201-6333 (Print) ISSN: 2201-6740 (Online) www.ijern.com.

\footnotetext{
${ }^{26}$ OSSREA, (2013): 184.

${ }^{27}$ L. Frick, R. Albertyn, R. Rutgers, (2010): 76-77.

${ }^{28}$ L. Frick, R. Albertyn, R. Rutgers, (2010): 94.

${ }^{29}$ Maxwell, W. E. 1998.
} 
Doctoral Research Supervision-Team Approach and Perspective of Socratic Method at the University of Rwanda (UR): Opportunity for Innovation

[9] Lambert N., \& McCombs B. (Eds.), (2000): How students learn Washington, D.C.: American Psychological Association, (1-15).

[10] Leathwood, C. (2001): The road to independence? Policy, pedagogy and "the independent learner" in higher education: University of East London.

[11] Leedy\&Ormrod, (2002): Practical Research: Planning and Design, 10th Edition. Paul D. Leedy, Late of The American University.

[12] Maxwell, W. E. (1998): Supplemental instruction, learning communities and students studying together. Community College Review (fall), retrieved December 20, 2005 from findarticles.com.

[13] McKinney, Kathleen and Chick, Nancy L. (2010): "SoTL as Women's Work: What Do Existing Data Tell Us?," International Journal for the Scholarship of Teaching and Learning: Vol. 4: No. 2, Article 16.

[14] Mclnerney, M.D and Mclnernery. V. (2002): Educational psychology - constructing learning, Australia, Catherine Godfrey.

[15] Murphy, P. K., \& Alexander, P. A. (2000): A motivated look at motivational terminology. [Special Issue]. Contemporary Educational Psychology, 25, 3-53.

[16] OSSREA, (2013): PhD Training in Eastern and Southern Africa: The experience of OSSREA, Tekeste Negash and Abiye daniel, Addis Abeba.

[17] Roger T. and David W. Johnson, (1991): An Overview Of Cooperative Learning.

[18] Slavin, R. E.(1990): Cooperative Learning. New Jersey: Prentice-Hall.

[19] Taylor, P. G. (2000): Changing Expectations: Preparing students for Flexible Learning. The International Journal of Academic Development 5(2), 107-115.

[20] Thomas J. Sergiovanni; Robert J.Starratt; Vingent Cho, (2014): Supervision: A redefinition, $9^{\text {th }}$ Edition, McGraw-Hill, New York.

[21] Walmsley, A.L. (2003): Cooperative learning and its effect in high school geometry classroom(Mathematics Teacher, 96(2), 112-116.

[22] Weimer, M. (2002): Learner-centered teaching. San Francisco: Jossey-Bass.

[23] Yamark, S. (2007): Does cooperative learning improves students' learning outcomes? Journal of Economic Education, 38(3)259-277.

\section{APPENDIX: RESEARCH QUESTIONNAIRE}

\section{Identification of Respondent}

1. Sex
a. Male
b. Female

2. Age
a. $25-40$
b. $41-55$
c. $56-65$

\section{Level of education}
a. Master
b. $\mathrm{PhD}$

\section{Category of respondents}
a. Candidate to $\mathrm{PhD}$
b. Supervisor

\section{Questionnaire}

\begin{tabular}{|c|c|c|}
\hline $\begin{array}{l}\text { Supervision-team approach in research process helps doctoral candidates work } \\
\text { together with their supervisors and hence the possibility of innovation. }\end{array}$ & YES & NO \\
\hline $\begin{array}{l}\text { Research supervision-team approach engages a doctoral candidate as well as supervisors in } \\
\text { the hard work of researching. }\end{array}$ & & \\
\hline
\end{tabular}


Doctoral Research Supervision-Team Approach and Perspective of Socratic Method at the University of Rwanda (UR): Opportunity for Innovation

\begin{tabular}{|l|l|l|}
\hline $\begin{array}{l}\text { Most of research activities involve problem-solving and investigational work, and involve } \\
\text { collaboration with supervisors. So the research supervision-team allows doctoral } \\
\text { candidates to be more active and take responsibilities in research process. }\end{array}$ & \\
\hline $\begin{array}{l}\text { Supervision-team plays a role of a facilitator by giving instructions, providing guidance, } \\
\text { monitoring candidates' research as well as inviting them to go deep in their innovation. }\end{array}$ & \\
\hline $\begin{array}{l}\text { Supervision-team's role is to make sure that the research is being a worthy and gives clear } \\
\text { way of innovation. }\end{array}$ & $\begin{array}{l}\text { Research supervision-team approach includes assignment components in which supervisors } \\
\text { and supervisee reflect, analyze and criticize what they are discovering and how they are } \\
\text { discovering it. }\end{array}$ & \\
\hline $\begin{array}{l}\text { With Socratic Method, what a doctoral candidate already knows largely determines what } \\
\text { new information he/she attends to, how he/she organizes and represents new information, and } \\
\text { how he filters new experiences, and even what he/she determines to be important or relevant. }\end{array}$ & \\
\hline $\begin{array}{l}\text { Through Socratic Method, with personal involvement, intrinsic motivation, personal } \\
\text { commitment, confidence in one's abilities to succeed, and a perception of control over } \\
\text { discovering lead to more discovering and higher achievement. }\end{array}$ & \\
\hline
\end{tabular}

\begin{tabular}{|c|c|c|}
\hline $\begin{array}{l}\text { There is quality improvement in doctoral research when supervisors are working } \\
\text { scientifically in team what enhances innovation }\end{array}$ & YES & NO \\
\hline $\begin{array}{l}\text { Having } 2 \text { or } 3 \text { supervisors, doctoral candidates commitments cannot be successful if the } \\
\text { dialogue under the form of Socratic Method is not involved. }\end{array}$ & & \\
\hline $\begin{array}{l}\text { Socratic method is applied questioning } \mathrm{PhD} \text { candidates to enable them to arrive at an } \\
\text { understanding of their reasoning and argument. }\end{array}$ & & \\
\hline $\begin{array}{l}\text { With Socratic Method, doctoral candidate becomes engaged in deeper thinking about } \\
\text { research outlines and its content, he/she brings additional knowledge to the science, and } \\
\text { group discussion between supervisors and the candidate brings up ideas, solves problems or } \\
\text { gives comments. }\end{array}$ & & \\
\hline $\begin{array}{l}\text { Research supervision-team approach embedded with Socratic method as interactive searching } \\
\text { facilitates the development of interpersonal skills and then can generate innovation. }\end{array}$ & & \\
\hline
\end{tabular}

\begin{tabular}{|l|l|l|}
\hline Socratic Method reduces candidates' lack of confidence in their doctoral research & YES & NO \\
\hline Supervisors (2 or 3 people at UR) share information among them and doctoral candidate. & & \\
\hline $\begin{array}{l}\text { The reason why the Socratic Method is suitable for research supervision-team is that it } \\
\text { removes fear and embarrassment from doctoral candidate in group discussion. }\end{array}$ & & \\
\hline $\begin{array}{l}\text { When the same instructions are being provided to the candidate by a supervisor, they are } \\
\text { being shared between supervisors in order to have the same way in supervision. }\end{array}$ & & \\
\hline $\begin{array}{l}\text { Research supervision-team approach requires that supervisors clearly understand the } \\
\text { overall content, as well as the appropriate order of knowledge. }\end{array}$ & & \\
\hline $\begin{array}{l}\text { Using Socratic Method, the doctoral candidate is assisted to break down the issues into } \\
\text { smaller units, and problem solving is focused on each of the smaller units rather than the } \\
\text { main issue. }\end{array}$ & & \\
\hline $\begin{array}{l}\text { Socratic Method helps in journey towards innovation. Until the candidates master how to } \\
\text { solve the problems in generalized situations. Supervisors continue to give prompts and } \\
\text { encouragement to aid the candidate's progress. }\end{array}$ & & \\
\hline $\begin{array}{l}\text { In this framework, research supervision-team approach fosters a reciprocal interaction. } \\
\text { This dialogue happens mainly in meeting and sometimes online. }\end{array}$ & \\
\hline $\begin{array}{l}\text { Along the supervision, doctoral candidates suggest that their supervisors should develop } \\
\text { techniques of dialogues: questioning, asking for clarification, and predicting. }\end{array}$ & & \\
\hline
\end{tabular}

Citation: Father Dr. Lucien Hakizimana. "Doctoral Research Supervision-Team Approach and Perspective of Socratic Method at the University of Rwanda (UR): Opportunity for Innovation " International Journal of Research in Sociology and Anthropology (IJRSA), vol 5, no. 1, 2019, pp. 20-27. doi:http://dx.doi.org/ 10.20431/2454-8677.0501003.

Copyright: (C) 2019 Authors. This is an open-access article distributed under the terms of the Creative Commons Attribution License, which permits unrestricted use, distribution, and reproduction in any medium, provided the original author and source are credited. 